\title{
Abundance dynamics and sequence variation of neomycin phosphotransferase gene (nptII) homologs in river water
}

\author{
Bin Zhu* \\ National Water Research Institute, Environment Canada, 11 Innovation Blvd, Saskatoon, Saskatchewan S7N 3H5, Canada
}

\begin{abstract}
Monitoring the abundance and dynamics of antibiotic resistance genes is essential for assessing their potential effects on environmental and human health. The objectives of the present study were to investigate: (1) the abundance of neomycin phosphotransferase (nptII) gene homologs in water samples collected monthly from the South Saskatchewan River (Canada) for 24 mo, and (2) sequence variation of the cloned nptII gene homologs retrieved from the river. DNA from river microbial communities was used to transform a natural competent Pseudomonas stutzeri strain containing a truncated nptII gene on a plasmid ( $P$. stutzeri pMR7). Of the 24 water samples, the recovery of kanamycin resistant $\left(\mathrm{Km}^{\mathrm{R}}\right)$ transformants from DNA of 4 samples indicated the presence of nptII gene homologous sequences. However, the natural transformation process required $\sim 3.2 \times 10^{4}$ copies of the nptII gene to recover a single $\mathrm{Km}^{\mathrm{R}}$ transformant. To overcome the limitation of detection, a realtime PCR assay using SYBR Green I was developed to quantify the abundance of nptII gene homologous sequences in river microbial communities. The results showed that nptII gene homologous sequences were present in the river, and their abundance varied over the course of this study, ranging from undetectable levels to $4.36 \times 10^{6}$ copies $\mathrm{l}^{-1}$ water. Furthermore, nptII gene homologous sequences amplified from river microbial community DNA were cloned, and unique clones were sequenced. Comparison of the nucleotide and deduced amino acid sequences of the cloned fragments to those of the nptII gene on transposon Tn5 showed that they had over 96\% homology.
\end{abstract}

KEY WORDS: Neomycin phosphotransferase gene $\cdot$ nptII $\cdot$ Abundance dynamics $\cdot$ Water samples Homologous sequence $\cdot$ Real-time PCR

Resale or republication not permitted without written consent of the publisher

\section{INTRODUCTION}

Among the mechanisms conferring bacterial antibiotic resistance, antibiotic resistance genes are particularly important because: (1) genetic elements coding for antibiotic resistance can be inherited from generation to generation and (2) bacteria can transfer them to other members of their own species and to other species via horizontal gene transfer (Davies 1994, Lorenz \& Wackernagel 1994). Meanwhile, antibiotic resistance genes are thought to evolve rapidly in response to antibiotic use, as evidenced by the ineffectiveness of some antibiotics (Davies 1994). This has led to the termination of clinical and veterinary use of many antibiotics since the discovery of penicillin in the 1920s.
Intriguingly, Sundin \& Bender (1996) showed that antibiotic resistance genes can persist even after the antibiotic use has diminished, implying that factors other than direct selection are also involved in the maintenance of these genes in natural environments.

Resistance to kanamycin (a member of the aminoglycoside family of antibiotics) in environmental bacteria is common (van Elsas 1992, Leff et al. 1993b). A number of mechanisms of kanamycin resistance have been identified in bacteria, one of which is the neomycin phosphotransferase (nptII) gene (Beck et al. 1982). Based on screening for kanamycin resistance $\left(\mathrm{Km}^{\mathrm{R}}\right)$ in the culturable fraction of bacteria in environmental samples, previous studies indicated that only a small number of $\mathrm{Km}^{\mathrm{R}}$ isolates carried the nptII gene; e.g. of 
the $350 \mathrm{Km}^{\mathrm{R}}$ bacterial isolates collected from water and soil samples by Smalla et al. (1993), only 3 isolates contained the nptII gene. Similarly, Leff et al. (1993a) detected 3 isolates carrying the nptII gene after screening $184 \mathrm{Km}^{\mathrm{R}}$ colonies isolated from river water samples.

It has been estimated that over $99 \%$ of bacteria in the environment are non-culturable in the laboratory (Amann et al. 1995). Thus, monitoring the abundance of the nptII gene in natural bacterial communities is a challenge because the nptII gene may be carried by non-culturable bacteria. To overcome this obstacle, molecular techniques have been exploited to investigate the prevalence of nptII gene homologous sequences in natural bacterial populations, with the involvement of microbial community DNA extraction and probe-based Southern blot hybridization (Leff et al. 1993a, Smalla et al. 1993). In recent years, real-time PCR has been widely used in quantifying bacterial genes including antibiotic resistance genes (Brennan \& Samuel 2003, Smith et al. 2004). Compared with conventional PCR-based assays, real-time PCR offers major advantages, including the large dynamic range of quantification and the exclusion of post-PCR manipulations, thus greatly reducing the risk of carry-over contamination. Meanwhile, real-time PCR can be performed on only minimal amounts of DNA and has a high-throughput capacity (Sharkey et al. 2004).

Most of the known antibiotic resistance genes have been discovered in clinical and veterinary bacterial strains, whereas their abundance and diversity in natural environments are not well characterized (Sèveno et al. 2002, Riesenfeld et al. 2004). In the present study, we described the quantification of nptII gene homologous sequences in water samples collected monthly from a river over a period of 24 mo. First, we monitored the presence of nptII gene homologous sequences in river microbial community DNA by testing their transforming ability with a competent Pseudomonas stutzeri strain harboring plasmid pMR7 (Meier \& Wackernagel 2003). Then we applied a real-time PCR assay using SYBR Green I to investigate the dynamics of abundance of nptII gene homologous sequences in river water. Further, homologous sequences of the nptII gene retrieved from river microbial communities were cloned and sequenced; their nucleotide and deduced amino acid sequences were compared to those of the nptII gene on transposon Tn5.

\section{MATERIALS AND METHODS}

Bacterial strains and plasmids. Pseudomonas stutzeri LO15 is a natural competent strain (Graupner et al. 2000). It was transformed to harbor a plasmid (pMR7) that contains the truncated nptII gene with a $10 \mathrm{bp}$ deletion (de Vries \& Wackernagel 1998), designated P. stutzeri pMR7 (Meier \& Wackernagel 2003). $P$. stutzeri pMR7 is sensitive to kanamycin. When cells of P. stutzeri pMR7 take up extracellular DNA carrying the nptII gene, the truncated gene can be restored through homologous recombination, thereby restoring the bacterial kanamycin resistance. Plasmid pNS1 (6.0 kb) harbored in Escherichia coli K-12 has the nptII gene (Sikorski et al. 2002).

Collection and filtration of water samples. The Saskatchewan River is Canada's fourth largest river, formed at the confluence of the North and South Saskatchewan Rivers more than $1200 \mathrm{~km}$ downstream from its glacial origins. This 8th order river crosses much of the prairie regions of central Canada, with the drainage encompassing approximately $364000 \mathrm{~km}^{2}$ (Rosenberg et al. 2005). In the present study, we collected river water samples monthly from the South Saskatchewan River, Saskatchewan, Canada, at one location during 2003 and 2004. A total of 24 water samples were obtained. At the time of sample collection, water temperatures ranged from $0.1^{\circ} \mathrm{C}$ (in the winter months) to $21.1^{\circ} \mathrm{C}$ (in the summer months). The $\mathrm{pH}$ was slightly above neutral ( $\mathrm{pH}$ range, 6.43 to 8.50 ; median $\mathrm{pH}=7.72$ ). Subsurface water (10 l) was collected from the river and immediately transported to the laboratory. If ice covered the river in winter, it was broken with an auger to collect water. Subsamples (1 1 river water) were filtered on a Millipore Durapore filter (pore size, $0.22 \mu \mathrm{m} ; 47 \mathrm{~mm}$ in diameter) to collect microbial biomass; 3 filters were collected for each sample. The filters were stored at $-80^{\circ} \mathrm{C}$ until DNA extraction.

DNA extraction. Frozen filters were thawed and cut into small pieces using a sterile razor blade prior to DNA extraction. Community DNA was extracted and purified from each filter using the Fast Soil DNA extraction kit (Qbiogene) and Beadbeater (Savant), following the manufacturers' instructions. Total DNA was eluted in $50 \mu \mathrm{l}$ double-distilled water $\left(\mathrm{ddH}_{2} \mathrm{O}\right)(25 \mu \mathrm{l}$ were used for natural transformation; $25 \mu \mathrm{l}$ and its serial 10-fold dilutions were used for PCR and real-time PCR). Plasmid DNA of pNS1, pMR7 and Pseudomonas stutzeri pMR7 $\mathrm{Km}^{\mathrm{R}}$ transformants was extracted from cells grown overnight in Luria-Bertani (LB) liquid culture $\left(37^{\circ} \mathrm{C}\right.$, shaking at $\left.250 \mathrm{rpm}\right)$ by the plasmid midi kit (Qiagen) following the manufacturer's instruction. DNA was quantified on a spectrofluorometer.

Natural transformation of Pseudomonas stutzeri pMR7. Transformation efficiency was tested based on the natural competent capacity of P. stutzeri pMR7 with plasmid pNS1 DNA. For transforming P. stutzeri pMR7 with DNA from river water, $5 \mu$ l of microbial community DNA was used as DNA donor for each 
transformation. Negative control was performed identically except for the omission of DNA. Transformation procedure was similar to the method described by Meier \& Wackernagel (2003), with minor modification. Briefly, cells of $P$. stutzeri pMR7 grown overnight in LB with streptomycin $\left(100 \mu \mathrm{g} \mathrm{ml}^{-1}\right)$ were washed twice with sterile $0.9 \% \mathrm{NaCl}$ and adjusted to a density of $\sim 1.0 \times 10^{9} \mathrm{cells} \mathrm{ml}^{-1}$. An aliquot $(50 \mu \mathrm{l})$ of cell suspension was then mixed with $5 \mu \mathrm{l}$ of river microbial community DNA. The mixtures were spotted onto one LB agar plate. After incubation for $20 \mathrm{~h}$ at $28^{\circ} \mathrm{C}$, the agar piece with the spot of cells was transferred to a glass tube containing $1 \mathrm{ml}$ of sterile $0.9 \% \mathrm{NaCl}$. The tube was vortexed to suspend the cells from the agar. Appropriate dilutions of the resuspended cells were plated on LB plates with kanamycin $\left(50 \mu \mathrm{g} \mathrm{ml}^{-1}\right)$ and incubated at $28^{\circ} \mathrm{C}$ for $3 \mathrm{~d}$ to determine the number of $\mathrm{Km}^{\mathrm{R}}$ colonies. The total number of bacterial colonies on LB plates was determined by serial dilutions. The transformation frequency was expressed as the percentage of $\mathrm{Km}^{\mathrm{R}}$ transformants over total viable recipient cells.

PCR analysis. The specific primers targeting the nptII gene used for PCR analysis are listed in Table 1. By using Primer Express software (Applied Biosystems), the primer set (nptII-532F and nptII-737R) was designed to flank the $10 \mathrm{bp}$ deletion of the nptII gene. Hence, they can be used to confirm the restoration of the nptII gene in $\mathrm{Km}^{\mathrm{R}}$ transformants. Their specificity to the nptII gene was verified by searching the GenBank database. All primers were purchased from Invitrogen. Amplification was conducted in a $20 \mu$ reaction

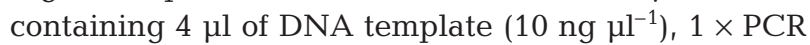
buffer (Promega), $0.1 \mu \mathrm{M}$ of each primer, $1 \mathrm{U}$ Taq DNA polymerase, $1.5 \mathrm{mM} \mathrm{MgCl}_{2}, 0.2 \mathrm{mM}$ of each deoxynucleotide triphosphate (dNTPs) and $\mathrm{ddH}_{2} \mathrm{O}$. The amplification program was as follows: 1 cycle of $95^{\circ} \mathrm{C}$ for $4 \mathrm{~min} ; 30$ cycles of $95^{\circ} \mathrm{C}$ for $30 \mathrm{~s}, 55^{\circ} \mathrm{C}$ for $45 \mathrm{~s}$, and $72^{\circ} \mathrm{C}$ for $1 \mathrm{~min}$, with a final cycle of $72^{\circ} \mathrm{C}$ for $7 \mathrm{~min}$. The PCR products were separated by electrophoresis in $2 \% \mathrm{w} / \mathrm{v}$ agarose in $1 \times$ Tris-acetate-EDTA (TAE) for $2.5 \mathrm{~h}$ at $103 \mathrm{~V}$. For the detection of the nptII gene in microbial community DNA by PCR, plasmid pNS1 was used as

Table 1. PCR primers used in this study. F: forward primer; R: reverse primer. Positions represent the open reading frame of the nptII gene on Tn5 transposon. Source: 1 = de Vries \& Wackernagel (1998), 2 = present study

\begin{tabular}{|llcc|}
\hline Primer & \multicolumn{1}{c}{ Sequence (5' to 3') } & Position & Source \\
\hline nptII-F & gaa caa gat gga ttg cac gc & $7-26$ & 1 \\
nptII-R & gat gtt tcg ctt ggt ggt c & $400-418$ & 1 \\
nptII-532F & atg ccc gac ggc gag gat ct & $532-551$ & 2 \\
nptII-737R & ata ccg taa agc acg agg aag cg & $715-737$ & 2 \\
\hline
\end{tabular}

a positive control. After electrophoresis, the gels were visualized by ethidium bromide staining and documented in a digital gel documentation system.

Real-time PCR analysis. During real-time PCR, the fractional cycle in which the increase in the fluorescence generated by the accumulation exceeds 10 standard deviations of the mean baseline fluorescence, with a selected range of cycles, is referred to as the threshold cycle $\left(C_{\mathrm{t}}\right)$. The $C_{\mathrm{t}}$ is inversely proportional to the starting amount of DNA (the initial quantity of a target gene), allowing the generation of standard curves by using samples containing serial 10 -fold dilutions of target genes. The primer set of nptII-F and nptII-R was used in real-time PCR. To establish a standard curve, copies of the nptII gene contained in plasmid pNS1 were calculated after DNA quantification and standards were prepared by serially diluting purified DNA of plasmid pNS1. The real time amplification plot was developed when the copy numbers used ranged from $1.0 \times 10^{7}$ to 10 copies per reaction. Briefly, river microbial community DNA and its serial 10-fold dilutions were used as DNA templates, DNA $(4 \mu \mathrm{l})$ was added to a reaction mixture containing $0.15 \mu \mathrm{M}$ of each primer, $12.5 \mu \mathrm{l}$ of $2 \times$ SYBR Green QPCR Master Mix (Stratagene), and sterile $\mathrm{ddH}_{2} \mathrm{O}$ in a final volume of $25 \mu l$. Real-time PCR was carried out with the SYBR Green (with Dissociation Curve) program on the Mx4000 Multiplex Quantitative PCR System (Stratagene). Cycling parameters were at $95^{\circ} \mathrm{C}$ for $10 \mathrm{~min}$ to denature, 40 cycles of $95^{\circ} \mathrm{C}$ for $30 \mathrm{~s}, 55^{\circ} \mathrm{C}$ for $1 \mathrm{~min}$, $72^{\circ} \mathrm{C}$ for $1 \mathrm{~min}$, followed by a melting curve analysis. The real-time PCR assay included a standard curve of 7 serial 10-fold dilution points of pNS1 (ranging from $1.0 \times 10^{7}$ to 10 copies of the nptII gene), and all reactions were performed in triplicate and the median $C_{\mathrm{t}}$ value was used for analysis. The melting curve analysis was performed to verify the correct product by its specific melting temperature $\left(T_{\mathrm{m}}\right)$. It consisted of a denaturation step at $95^{\circ} \mathrm{C}$ for $1 \mathrm{~min}$, lowered to $55^{\circ} \mathrm{C}$ for $30 \mathrm{~s}$, and followed by 40 cycles of heating the samples to $95^{\circ} \mathrm{C}$ with continuous reading of fluorescence.

Cloning nptII gene homologous fragments. For cloning homologous sequences of the nptII gene from river microbial communities, the primer set of nptII-F and nptII-737R was chosen because it covered the major portion of the nptII gene and excluded a conserved region (located at the end of the open reading frame of the nptII gene) that was shared by other aminolyocoside phosphotransferase sub-families (Shaw et al. 1993). DNA from the water samples in which nptII gene homologous sequences were detected by real-time PCR was combined and PCR was run as described above. After electrophoresis on an agarose gel, amplified DNA was excised and purified by a Qiaquick gel extraction kit (Qiagen). Subsequently, 
purified PCR products were ligated into the pDrive cloning vector, and then introduced into competent Escherichia coli cells by heat shock transformation following the manufacturer's instructions (Qiagen). Clones containing the correct insert were confirmed by PCR amplification with the universal primers T7 and sP6. Subsequently, the amplified fragments were digested by restriction enzymes to identify unique clones, which were detected by restriction fragment length polymorphism (RFLP) analysis first with MspI plus RsaI, and for clones not resolved with HhaI plus HaeIII. Based on digestion patterns, plasmid DNA was purified for unique inserts using a Qiagen plasmid mini kit and the concentration of plasmid DNA was determined by a spectrophotometer prior to sequencing.

DNA sequencing and phylogenetic analysis. DNA sequences were determined on both strands of the purified plasmid DNA as template by automated fluorescent Taq cycle sequencing using ABI 377 Sequencers (Applied Biosystems). Similarity searches against sequence database were performed using an updated version of the BLAST program at the National Center for Biotechnology Information server (www. ncbi.nlm.nih.gov). The phylogenetic relationship was constructed using the maximum likelihood program in the PAUP4.0 package (http://paup.csit.fsu.edu) after nptII gene homologous sequence and their amino acid alignments were calculated using ClustalW (Thompson et al. 1994). The unrooted phylogenetic consensus tree was generated using Treeview (Page 1996).

Nucleotide sequence accession number. The nucleotide sequences reported in the present study have been submitted to the GenBank sequence database and assigned the accession numbers DQ449894 to DQ449904.

\section{RESULTS}

\section{Natural transformation of Pseudomonas stutzeri pMR7 with river microbial community DNA}

To detect the potential presence of nptII gene homologous sequences contained in river microbial communities, we used river microbial DNA to transform Pseudomonas stutzeri pMR7, which is sensitive to kanamycin because of the deletion (10 bp) of the nptII gene on plasmid pMR7. The results showed that $\mathrm{Km}^{\mathrm{R}}$ transformants were recovered from 4 water samples with a transformation frequency range of 1.48 to $5.13 \times 10^{-7}$ (Table 2). Meanwhile, no $\mathrm{Km}^{\mathrm{R}}$ colonies were detected when P. stutzeri pMR7 cells were cultured without plasmid DNA as negative control. Further, to confirm that kanamycin resistance shown by $\mathrm{Km}^{\mathrm{R}}$ transformant colonies was attributable to the restoration of the truncated nptII gene, we extracted
Table 2. Number of kanamycin-resistant $\left(\mathrm{Km}^{\mathrm{R}}\right)$ transformants recovered from transforming Pseudomonas stutzeri pMR7 with river microbial community DNA extracted from $1 \mathrm{l}$ of water, expressed as the mean of 3 filters \pm SD. The detection limit is ca. $3.0 \times 10^{-8}$

\begin{tabular}{|lccc|}
\hline Date & $\begin{array}{c}\text { Amount of } \\
\text { DNA }(\mu \mathrm{g})\end{array}$ & $\begin{array}{c}\mathrm{Km}^{\mathrm{R}} \\
\text { transformants }\end{array}$ & $\begin{array}{c}\text { Transformation } \\
\text { frequency }\left(\times 10^{-7}\right)\end{array}$ \\
\hline $\mathbf{2 0 0 3}$ & & & \\
Feb 12 & $18.25 \pm 1.23$ & $48.7 \pm 12.5$ & $1.48 \pm 0.31$ \\
Dec 11 & $22.90 \pm 1.19$ & $36.6 \pm 7.5$ & $5.13 \pm 0.55$ \\
$\mathbf{2 0 0 4}$ & & & \\
Sep 13 & $22.05 \pm 1.86$ & $32.1 \pm 7.3$ & $3.11 \pm 0.63$ \\
Dec 7 & $16.90 \pm 1.47$ & $56.2 \pm 10.8$ & $3.15 \pm 0.47$ \\
\hline
\end{tabular}

plasmid DNA from $\mathrm{Km}^{\mathrm{R}}$ transformants and amplified with the primer set of nptII-532F and nptII-737R (flanking the $10 \mathrm{bp}$ deletion of the nptII gene on plasmid pMR7). The result showed that a $206 \mathrm{bp}$ fragment from the nptII gene was amplified (Fig. 1), indicating that the $10 \mathrm{bp}$ deletion of the nptII gene on plasmid pMR7 was restored. Together with the recovery of $\mathrm{Km}^{\mathrm{R}}$ transformants, this result demonstrated that nptII gene homologous sequences were present in river microbial communities and that they could restore the biological activity of the truncated nptII gene in P. stutzeri pMR7 by homologous recombination.

\section{Reproducibility of real-time PCR assay}

After testing the transformation efficiency of Pseudomonas stutzeri pMR7 with plasmid pNS1 DNA, we observed that a minimum of $3.2 \times 10^{4}$ copies of the nptII gene were needed to obtain a single $\mathrm{Km}^{\mathrm{R}}$ transformant (Fig. 2). This limitation of detection could underestimate the abundance of nptII gene homolo-

$$
\begin{array}{lllllllll}
1 & 2 & 3 & 4 & 5 & 6 & 7 & 8 & 9
\end{array}
$$

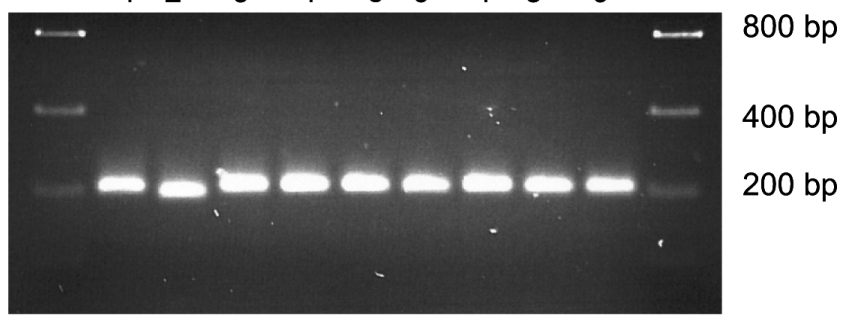

Fig. 1. Amplification of the specific fragment containing the $10 \mathrm{bp}$ deletion in the nptII gene on plasmid pMR7 and its kanamycin-resistant $\left(\mathrm{Km}^{\mathrm{R}}\right)$ transformants. After Pseudomonas stutzeri pMR7 was transformed with DNA from river microbial communities, plasmid DNA from individual $\mathrm{Km}^{\mathrm{R}}$ transformants was amplified with the primer set of nptII-532F and nptII-737R (flanking the $10 \mathrm{bp}$ deletion of the nptII gene). Lane 1: plasmid pNS1; Lane 2: plasmid pMR7; Lanes 3 to 9: 7 individual $\mathrm{Km}^{\mathrm{R}}$ transformants 


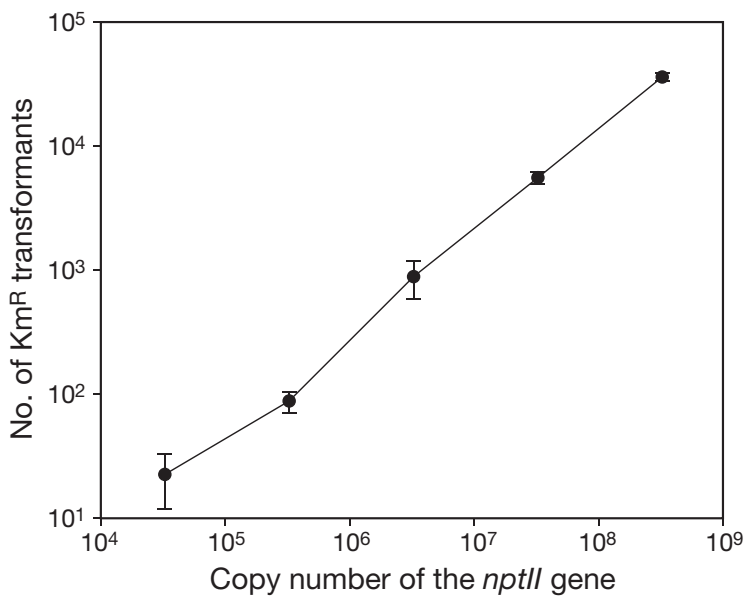

Fig. 2. Transformation efficiency of Pseudomonas stutzeri pMR7 with the indicated copies of the nptII gene carried by plasmid pNS1. Data $( \pm \mathrm{SD})$ are the mean of 3 independent experiments

gous sequences in river water samples. Therefore, we applied a real-time PCR assay using SYBR Green I to quantify the abundance of nptII gene homologous sequences. Prior to application of real-time PCR, a BLAST search in the ENTREZ database was performed to confirm the specificity of the primer set (nptII-F and nptII-R). Subsequently, the quantification sensitivity of real-time PCR was conducted by using serially 10-fold diluted DNA of plasmid pNS1 containing the nptII gene (equivalent to 10 to $1.0 \times 10^{7}$ copies of target). The results demonstrated that a typical amplification plot (Fig. 3A) and a high correlation in the standard curve $\left(\mathrm{R}^{2}=0.997\right)$ (Fig. 3B) were generated. The melting curve analysis showed a single peak $\left(T_{\mathrm{m}}=87.5^{\circ} \mathrm{C}\right)$, confirming the specificity of the amplified PCR fragment (Fig. 3C). Further, the reproducibility of the real-time PCR assay was assessed by measuring $C_{\mathrm{t}}$ values for 4 replicates of the standards (Table 3). The results represented independent dilution series and different PCR runs. The mean $C_{\mathrm{t}}$, standard deviation, and percent coefficient of variation (\% CV) were calculated for each template concentration. The results showed low variability, with \% CVs ranging from 0.81 to $2.52 \%$, indicating that the assay was efficiently reproducible.

\section{Abundance dynamics of nptII gene homologous sequences in river water over 24 mo}

Real-time PCR was applied to quantify the abundance of nptII gene homologous sequences present in river water samples collected over 24 mo. For each sample, river microbial community DNA and its serially diluted concentrations (typically $10^{-1}$ to $10^{-2}$ ) were run by real-time PCR to determine the copy number of nptII gene homologous sequences. After real-time $\mathrm{PCR}$, the specificity of the amplified fragments generated from river community DNA was confirmed by the dissociation curve analyses, which had a $T_{\mathrm{m}}$ of $87.5^{\circ} \mathrm{C}$ (data not shown). The results showed that the abundance of nptII gene homologous sequences varied considerably over the course of this study (Table 4). Although nptII gene homologous sequences were not detected in most of the water samples, they were present in 9 samples. The abundance was as high as $4.36 \times 10^{6}$ copies $\mathrm{l}^{-1}$ water in the sample collected on February 12,2003 , and $4.60 \times 10^{5}$ in the sample of September 13, 2004.

\section{PCR amplification and restriction digestion of the nptII gene homologous fragments}

To investigate the potential genetic variation of $n p t I I$ gene homologous sequences in microbial communities of the river, we combined microbial community DNA from the 9 water samples in which nptII gene homologous sequences were detected. A major portion of the nptII gene was amplified from the combined DNA with the primer set of nptII-F and nptII-737R for cloning, representing $731 \mathrm{bp}$ of the neomycin phosphotransferase coding region (792 bp). In total, 122 clones containing the correct insert were obtained. After digestion with the 2 rounds of restriction enzyme combinations, 11 clones were identified as unique sequences based upon their digestion pattern.

\section{Phylogenetic relationship among the nptII gene homologous sequences}

Homology searches in GenBank using the BLAST program revealed that all 11 clones showed high levels of sequence identity ( $>97.9 \%$ ) to that of the nptII gene (GenBank accession V00618) on Tn5 (Fig. 4), with most having 4 to 6 nucleotide substitutions, deletions, or insertions at various nucleotide positions. Clone K025 had the most nucleotide changes (15 of 731) compared to that of the nptII gene. This result indicates that there is sequence variation among the cloned fragments retrieved from the river.

\section{Conservation of the deduced amino acid sequence of the nptII gene fragments}

The cloned 731 bp fragment represented 243 of the total 264 amino acids of the neomycin phosphotransferase encoded by the nptII gene, designated $\mathrm{APH}\left(3^{\prime}\right)$ - 

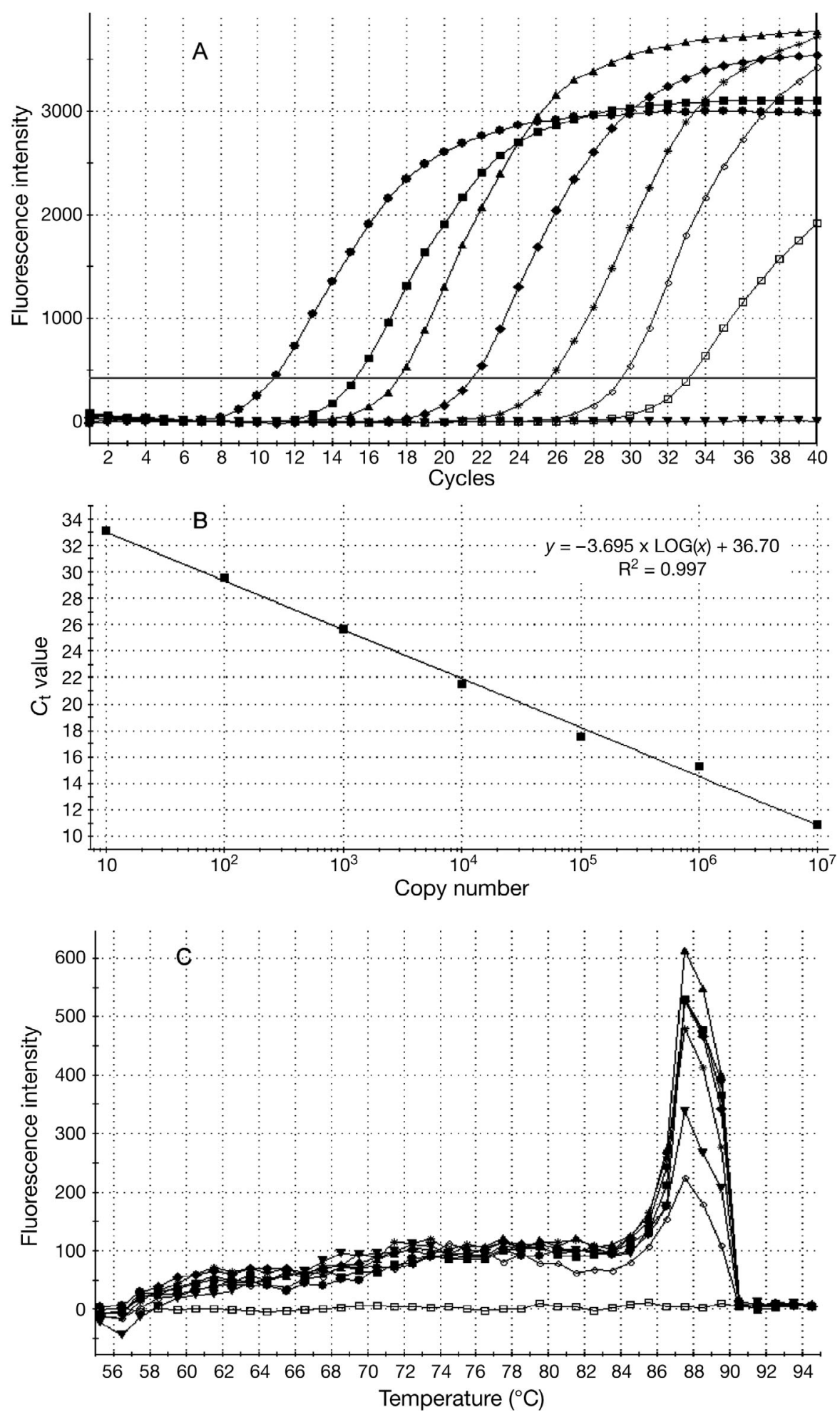

Fig. 3. Establishment of the standard curve for quantifying the nptII gene. (A) Amplification plots of the nptII gene standards. The copy number of the nptII gene is (from left to right) $1.0 \times 10^{7}, 1.0 \times 10^{6}, 1.0 \times 10^{5}, 1.0 \times 10^{4}, 1.0 \times 10^{3}, 1.0 \times 10^{2}$ and 10 , with a nontemplate control showing no amplification. (B) Standard curve was generated from the threshold $\left(C_{\mathrm{t}}\right)$ values of the amplification plots with Stratagene Mx 4000. This curve represents the standard curve only; no unknowns are represented. (C) Dissociation curve analysis shows a melting point of $87.5^{\circ} \mathrm{C}$
IIa (Shaw et al. 1993). Subsequently, the deduced amino acid of the cloned fragments was aligned and compared with the amino acid sequence of the nptII gene (Fig. 5). The results showed that these sequences shared a high similarity with that of the nptII gene (>96\% identity). Clone K025 shared a 96\% identity and $98 \%$ similarity with that encoded by the nptII gene.

\section{DISCUSSION}

Previous studies have demonstrated that although only a small portion of culturable $\mathrm{Km}^{\mathrm{R}}$ bacterial strains carried the nptII gene, the presence of nptII gene homologous sequences in DNA extracted from natural microbial communities was detected using Southern blot analyses with the nptII gene as probes (Leff et al. 1993a, Smalla et al. 1993). To assess the abundance of nptII gene homologous sequences in environments, their abundance in both culturable and non-culturable bacterial populations should be known (Smalla et al. 1993, Sèveno et al. 2002). The realtime PCR assay used in the present study proved useful for quantifying the abundance of nptII gene homologous sequences in microbial communities. It allowed the specific amplification of the nptII gene DNA over a 7-log DNA concentration range. The specificity of the assay was confirmed by a search for primer-specific sequences with the BLAST program and melting curve analyses. Taken together, it can be applied to quantify the abundance of nptII gene homologous sequences when a large number of environmental samples need to be screened.

For bacterial kanamycin resistance, both spatial and temporal differences in the frequency of the nptII gene were observed in some aquatic environments, suggesting that a large number of samples should be studied to obtain a representative gene frequency in an ecosystem (Leff et al. 1993a, McArthur \& Tuckfield 2000). Variation of the abundance of nptII gene homologous sequences detected in the river system 
Table 3. Summary of copy number of nptII gene and threshold cycle $\left(C_{\mathrm{t}}\right)$ values that were generated from 4 different realtime PCR runs performed on 4 separate dilution series of the nptII gene contained in plasmid pNS1 DNA. Mean $C_{\mathrm{t}}$ : average $C_{\mathrm{t}}$ value of the 4 independent real-time PCR runs; CV: ratio between $\mathrm{SD}$ and the mean of the repeated measurements multiplied by 100

\begin{tabular}{|lccc|}
\hline Copy number & Mean $C_{\mathrm{t}}$ & $\mathrm{SD}$ & $\% \mathrm{CV}$ \\
\hline $10^{7}$ & 10.94 & 0.35 & 2.17 \\
$10^{6}$ & 15.39 & 0.19 & 1.12 \\
$10^{5}$ & 17.73 & 0.15 & 0.88 \\
$10^{4}$ & 21.45 & 0.14 & 0.81 \\
$10^{3}$ & 25.91 & 0.26 & 1.47 \\
$10^{2}$ & 29.35 & 0.31 & 1.19 \\
$10^{1}$ & 32.65 & 0.44 & 2.52 \\
\hline
\end{tabular}

over a period of 24 mo was observed in this study. Of the 24 water samples, 9 showed the presence of nptII gene homologous sequences, with copy number ranging from $1.26 \times 10^{3}$ to $4.36 \times 10^{6} \mathrm{l}^{-1}$ water, implying temporal changes in the abundance of nptII gene homologous sequences in the river system. Smalla et al. (1993) suggested that the occurrence of the nptII gene in freshwater environments might be due to discharges of sewage, animal manure and municipal wastewater that entered to open waters in a largely uncontrolled fashion. Obviously, these sources may contain bacteria carrying nptII gene homologous sequences or impose a strong selection pressure (McArthur \& Tuckfield 2000). Meanwhile, Leff et al. (1993a) reported the non-random occurrence of the nptII gene in a pristine stream with bank sediments that had a higher abundance than channel sediments or submerged leaf surfaces. Therefore, in addition to agricultural, medical, or sewage sources, some biogeochemical processes and selective factors may be associated with the occurrence frequency of different antibiotic resistance

Fig. 4. Phylogenetic relationship of the cloned nptII gene homologous sequences retrieved from the river. The unrooted tree was constructed using the parsimony analysis (PAUP4.0 package) after the alignment of the nptII homologous sequence was calculated using the ClustalW program. The tree was derived using the Treeview program. The bootstrap analysis was conducted using 1000 replicates; bootstrap values $>50$ are shown on internal nodes. Scale bar represents 0.01 nucleotide chances per nucleotide position. Clones K001, K002, K003, K009, K025, K036, K040, K047, K048, K049, and K056 correspond to GenBank accession numbers DQ449898, DQ449903， DQ449900， DQ449894， DQ 449904, DQ449897, DQ-449896, DQ449901， DQ449899, DQ449895, and DQ-449902, respectively
Table 4. Copy number of nptII gene homologous sequences in $1 \mathrm{l}$ of water collected monthly from the South Saskatchewan River in 2003 and 2004. For each water sample, data are expressed as the mean of triplicate real-time PCR runs \pm SD. ND: not detected $\left(<1.0 \times 10^{3}\right.$ copies ${ }^{-1}$ water $)$

\begin{tabular}{|c|c|}
\hline Date & Copy number \\
\hline \multicolumn{2}{|l|}{2003} \\
\hline Jan 8 & ND \\
\hline Feb 12 & $4.36 \pm 0.42 \times 10^{6}$ \\
\hline Mar 21 & $2.51 \pm 0.79 \times 10^{3}$ \\
\hline Apr 2 & ND \\
\hline May 12 & ND \\
\hline Jun 28 & ND \\
\hline Jul 16 & ND \\
\hline Aug 11 & ND \\
\hline Sep 10 & ND \\
\hline Oct 10 & $2.15 \pm 0.54 \times 10^{3}$ \\
\hline Nov 13 & ND \\
\hline Dec 11 & $3.14 \pm 0.81 \times 10^{5}$ \\
\hline \multicolumn{2}{|l|}{2004} \\
\hline Jan 8 & $1.69 \pm 0.47 \times 10^{3}$ \\
\hline Feb 9 & ND \\
\hline Mar 8 & $4.92 \pm 0.87 \times 10^{3}$ \\
\hline Apr 18 & ND \\
\hline May 7 & ND \\
\hline Jun 9 & ND \\
\hline Jul 12 & ND \\
\hline Aug 6 & ND \\
\hline Sep 13 & $4.60 \pm 0.72 \times 10^{5}$ \\
\hline Oct 14 & ND \\
\hline Nov 10 & $1.26 \pm 0.36 \times 10^{3}$ \\
\hline $\operatorname{Dec} 7$ & $6.85 \pm 0.52 \times 10^{4}$ \\
\hline
\end{tabular}

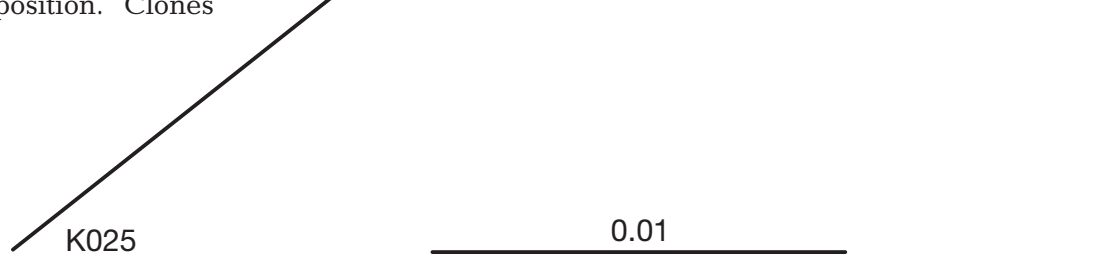


K036

K0 40

Tn 5

K002

K048

K001

K0 47

K009

K0 49

$\mathrm{K} 003$

K056

K025

X90856

AJ278514

K036

K040

Tn5

$\mathrm{K} 002$

K0 48

K001

K047

K009

K049

$\mathrm{K} 003$

K05 6

K025

$\times 90856$

AJ278514

K036

K0 40

Tn 5

$\mathrm{KOO} 2$

K0 48

K001

K0 47

K009

K0 49

$\mathrm{K} 003$

K056

K02 5

X90856

AJ2 78514

K036

K040

Tn5

K002

K0 48

$\mathrm{K} 001$

K0 47

K009

K049

$\mathrm{K} 003$

K05 6

K025

X90856

AJ278514

K036

K0 40

Tn5

$\mathrm{KOO} 2$

K048

$\mathrm{K} 001$

K0 47

K009

K0 49

K003

K056

K025

X90856

AJ278514

EQDGLHAGSPAAWVERLFGYDWAQQTIGCSDVAVFRLSAQGRPVLFVKTDLSGALNELQD 60 -LDGLHAGSPAAWVERLFGYDWAQQTIGCSDAAVFRLSAQGRPVLFVKTDLSGALNELQD 59 EQDGLHAGSPAAWVERLFGYDWAQQTIGCSDAAVFRLSAQGRPVLFVKTDLSGALNELQD 60 EQDGLHAGSPAAWVERLFGYDWAQQTIGCSDAAVFRLSAQGRPVLFVKTDLSGALNELQD 60 EQDGLHAGSPAAWVERLFGYDWAQQTIGCSDAAVFRLSAQGRPVLFVKTDLSGALNELQD 60 EQDGLHAGSPAAWVERLFGYDWAQQTIGCSDAAVFRLSAQGRTVLFVKTDLSGALNELQD 60 EQDGLHAGSPAAWVERLFGYDWAQQTIGCSDAAVFRLSAQGRPVLFVKT DLSGALNELQD 60 -DDGLHAGSPAAWVERLFGHDWAQQTIGCSDAAVFRLSAQGRPVLFVKTDLSGALNELQD 59 IQIGLHAGSPAAWVERLFGYDWAQQTIGCSDAAVFRLSAQGRPVLFVKTDLSGALNELQD 60 EQDGLHAGSPAAWVERLFGYDWAQQTIGCSDAAVFRLSAQGRPVLFVKTDLSGALNELQD 60 EQDGLHAGSPAAWVERLFGYDWAOQTIGCSDAAVFRLSARGRPVLFVKTDLSGALNELQD 60 EQDGLHAGSPAAWVERLFGYDWAQQTIGCSDAAVFRLSAQGRPVLFVKTDLSGALNELQD 60 AATSMPPQAPSTWADYLAGYRWRGQGEGCSAATVHRLEAARRPTLFVKQEVLSAHAELPA 60 VALDEVSELKNLLSPLLDECTFEEVEYGQSDARVIRVLFPDRNTAYLKYASGSSAOEILQ 60

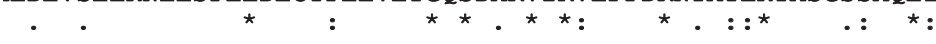

EAARLSWLATTGVPCAAVLDVVTEAGRDWLLLGEVPGQDLLS----SHLAPAEKVS IMAD 116 EAARLSWLATTGVPCAAVLDVVTEAGRDWLLLGEVPGQDLLS----SHLAPAEKVSIMAD 115 EAARLSWLATTGVPCAAVLDVVTEAGRDWLLLGEVPGQDLLS----SHLAPAEKVSIMAD 116 EAARLSWLATTGVPCAAVLDVVTEAGRDWLLLGEVPGQDLLS----SHLAPAEKVS IMAD 116 EAARLSWLATTGVPCAAVLDVVTEAGRDWLLLGEVPGQDLLS----SHLAPAEKVS IMAD 116 EAARLSWLATTGVPCAAVLDVVTEAGRDWLLLGEVPGQDLLS----SHLAPAEKVSIMAD 116 EAARLSWLATTGVPCAAVLDVVTEAGRDWLLLGEVPGQDLLS----SHLAPAEKVS IMAD 116 EAARLSWLATTGVPCAAVLDVVTEAGRDRLLLGEVPGQDLLS----SHLAPAEKVSIMAD 115 EAARLSWLATTGVPCAAVLDVVTEAGRDWLLLGEVPGQDLLS----SHLAPAEKVSIMAD 116 EAARLSWLATTGVPCAAVLDVVTEAGRDWLLLGEVPGQDLLS----SHLAPAEKVPIMAD 116 EAARLSWLATTGVPCAAVLDVVTEAGRDWLLLGEVPGQDLLS----SHLAPAEKVS IMAD 116 EAARLSWLATTGVPCAAVLDVVTEAGRDWLLLGEVPGQDLLS----SHLAPAEKVSIMAD 116 EIARLRWLHGAGIDCPQVLNETQSDGRQWLLMSAMPGDTLSALAORDELEPERLVRLVAA 120 EHQRTRWLRTR-ALVPEVISYVSTSTVTILLTKALIGHNAAD---AADADPVIVVAEMAR 116

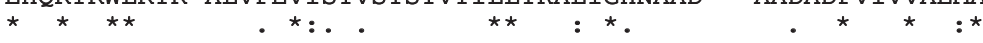

AMRRLHTLDPATCPFDHOAKHRIERARTRMEAGLVDODDLDEEHOGLAPAELFARLKARM 176 AMRRLHTLDPATCPFDHQAKHRIERARTRMEAGLVDQDDLDEEHQGLAPAELFARLKARM 175 AMRRLHTLDPATCPFDHQAKHRIERARTRMEAGLVDQDDLDEEHQGLAPAELFARLKARM 176 AMRRLHTLDPATCPFDROAKHRIERARTRMEAGLVDODDLDEEHOGLAPAELFARLKARM 176 AMRRLHTLDPATCPFDHQAKHRIERARTRMEAGLVDQDDLDEEHQGLAPAELFARLKARM 176 AMRRLHTLDPATCPFDHQAKHRIERARTRMEAGLVDQDDLDEEHQGLAPAELFARLKARM 176 AMRRLHTLDPATCPFDHOAKHRIERARTRMEAGLVDODDLDEEHOGLAPAELFARLKARM 176 AMRRLHTLDPATCPFVHQAKHRIERARTQMEAGLVDQDDLDEEHQGLAPAELFARLKARM 175 AMRRLHTLDPATCPFDHQAKHRIERARTRMEAGLVDQDDLDEEHQGLAPAELFARLKARM 176 AMRRLHTLDPATCPFNHQAKHRIERARTRMEAGLVDODDLDEEHQGLAPAELFARLKARM 176 AMRRLHTLDPATCPFDHQAKHRIERARTRMEAGLVDQDDLDEEHQGLAPAGLFAGLKARM 176 AMRRLHTLDPATC PFDHQAKHRIERARTRMEAGLVDQDDLDEEHQGPAPAELFARLKARM 176 ALRRLHDLDPAACPFDHRLERRLDTVRQRVEAGLVDEADFDDDHRGRSATELYRLLLDRR 180 ALRDLHSISPDDCPFDERLHLRLKLASGRLEAGLVDEEDFDHARQGMLARDVYEQLFIQM 176

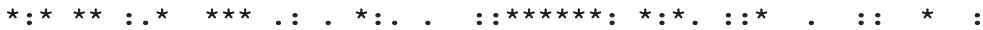

PDGEDLVVTHGDACLPNIMVENGRFSGFIDCGRLG-ADRYQDIALATRDIAEELGGEWAD 235 PDGEDLVVTHGDACLPNIMVENGRFSGFIDCGRLGVADRYQDIALATRDIAEELGGEWAD 235 PDGEDLVVTHGDACLPNIMVENGRFSGFIDCGRLGVADRYOD IALATRDIAEELGGEWAD 236 PDGEDLVVTHGDACLPNIMVENGRFSGFNDCGRLGVADRYQDIALATRDIAEELGGEWAD 236 PDGEDLVETHGDACLPNIMVENGRFSGFIDCGRLGVADRYQDIALATRDIAEELGGEWAD 236 PDGEDLVVTHGDACLPNIMVENGRFSGFIDCGRLGVADRYODIALATRDIAEELGGEWAD 236 PDGEDLVVTHGDACLPNIMVEIGRFSGFIDCGRLGVADRYQDIALATRDIAEELGGEWAD 236 PDGEDLVVTHGDACLPNIMVENGRFSGFIDCGRLGVADRYQDIALATRDIAEELGGEWAD 235 PDGEDLVVTHGDACLPNIMVENGRFSGFIDCGQLGVADRYODIALATRDIAEELGGEWAD 236 PDGEDLVVTHGDACLPNIMVENGRFSGFIDCGRLGVADRYQDIALATRDIAEELGGEWAD 236 PDGEDLVVTHGDACLPNIMVENGRFSGFIDCGRLGVADRYQDIALATRDIAEELGGEWAD 236 PDGEDLVVTHGDACLPNIMVENGRFSGFID-GRLGVADRYODIALATRDIAEELGGERAD 235 PAVEDLVVAHGDACLPNLLAEGRRFSGFIDCGRLGVADRHQDLALAARDIEAELGAAWAE 240 PGAEQLVVTHGDACPENFIFQGNAFVGFIDCGRVGLADKYQDLALASRNIDAVFGPELTN 236

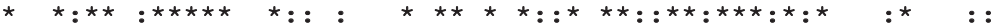

RRLVLYG 242

RRLVLYG 242

RFLVLYG 243

R-LVLYG 242

R-LVLYG 242

R-LVLYG 242

R-LVLYG 242

R-LVLYG 241

R-LVLYG 242

R-LVLYG 242

R-LVLYG 242

R-LVLIT 241

AFLVEYG 247

QFFIEYG 243

: :
Fig. 5. Comparison of the deduced amino acid sequences encoded by the nptII gene homologs and their closest relative, the nptII gene [APH(3')-IIa] on Tn5. Also included are 2 members (EMBL accession X90856 and GenBank accession AJ278514) of the APH(3')-IIb, characterized in Pseudomonas aeruginosa and Achromobacter xylosoxydans, respectively. Identical residues are each indicated by an asterisk; conservative amino acid substitutions are each indicated by a colon; and semi-conservative amino acid substitutions are each indicated by a dot. The 2 of the 3 highly conserved motifs that are known to be involved in catalytic activity of the APH enzymes are overlined 
traits in some environments (Sundin \& Bender 1996, McArthur \& Tuckfield 2000). For instance, metal resistance genes and antibiotic resistance genes were often found on the same plasmids or mobile genetic elements in natural microbial communities (Wireman et al. 1997, Yurieva et al. 1997), implying that antibiotic resistance under natural conditions is made more complex by frequent genetic association with metal resistance genes (McArthur \& Tuckfield 2000). Future studies on this genetic association would shed light on the persistence and evolution of antibiotic resistance genes in natural environments.

Cultured microorganisms, especially clinical bacterial strains, have been the major source of most of the known antibiotic resistance genes. In recent years, a few studies have demonstrated that natural environments may harbor a reservoir of antibiotic resistance genes (Sèveno et al. 2002, Riesenfeld et al. 2004), emphasizing that antibiotic resistance genes and their diversity in natural environments need to be characterized. Meanwhile, Waters \& Davies (1997) suggested that sequence analysis of genetic elements conferring potential antibiotic resistance in microbial communities would be valuable both in predicting mechanisms of resistance likely encountered in subsequent clinical use and in understanding the evolution of bacterial antibiotic resistance. For instance, previous studies have identified conserved sequences within the phosphotransferase coding region by investigating aminoglycoside-resistant mutants with alterations in amino acid sequences and changes in the resistance profiles (Yenofsky et al. 1990). For the amino acid sequence of aminoglycoside resistance genes of the $\mathrm{APH}\left(3^{\prime}\right)$-II type, there were 3 highly conserved motifs identified to be involved in the catalytic activity of the APH enzymes (Shaw et al. 1993). On comparison with the nptII gene, APH(3')-IIa, and 2 members (EMBL accession X90856 and GenBank accession AJ278514) of the APH (3')-IIb, 2 of the 3 motifs were located within the cloned region of the nptII gene homologous fragments (Fig. 5). It was evident that these 2 enzyme-binding sites were highly conserved among the cloned sequences, supporting the opinion that the conserved regions of the neomycin phosphotransferase-coding sequence were important enzyme-binding domains.

The results from the real-time PCR analyses demonstrated that nptII gene homologous sequences were present in microbial communities of the South Saskatchewan River and that their abundance varied over the course of a $2 \mathrm{yr}$ period. Meanwhile, the comparison of the nucleotide and deduced amino acid sequences of the cloned nptII homologous fragments to those of the nptII gene on transposon Tn5 showed that they had high levels of homology (>96\%). Further studies to quantify the abundance of nptII gene homol- ogous sequences at different spatial scales in the river will generate a representative gene frequency in the ecosystem and shed light on the mechanisms underlying the persistence of the antibiotic resistance gene.

Acknowledgements. The research was financially supported by the Canadian Environmental Protection Act (CEPA) and the National Water Research Institute, Environment Canada. The author is grateful to Dr. J. Maguire for his insightful comments on an earlier version of the manuscript and to the 3 anonymous reviewers for their thoughtful reviews, which resulted in a much-improved manuscript. The author also thanks Dr. W. Wackernagel for kindly providing the markerrescue system and J. Roy for technical assistance.

\section{LITERATURE CITED}

Amann RI, Ludwig W, Schleifer KH (1995) Phylogenetic identification and in situ detection of individual microbial cells without cultivation. Microbiol Rev 59:143-169

Beck E, Ludwig G, Auerswald EA, Reiss B, Schaller H (1982) Nucleotide sequence and exact localization of the neomycin phosphotransferase gene from transposon Tn5. Gene 19:327-336

Brennan RE, Samuel JE (2003) Evaluation of Coxiella burnetii antibiotic susceptibilities by real-time PCR assay. J Clin Microbiol 41:1869-1874

Davies J (1994) Inactivation of antibiotics and the dissemination of resistance genes. Science 264:375-382

de Vries J, Wackernagel W (1998) Detection of nptII (kanamycin resistance) genes in genomes of transgenic plants by marker-rescue transformation. Mol Gen Genet 257:606-613

Graupner S, Frey V, Hashemi R, Lorenz MG, Brandes G, Wackernagel W (2000) Type IV pilus genes pilA and pilC of Pseudomonas stutzeri are required for natural genetic transformation, and pilA can be replaced by corresponding genes from nontransformable species. J Bacteriol 182:2184-2190

Leff LG, Dana JR, McArthur V, Shimkets LJ (1993a) Detection of Tn5-like sequences in kanamycin-resistant stream bacteria and environmental DNA. Appl Environ Microbiol 59:4417-4421

Leff LG, McArthur JV, Shimkets LG (1993b) Spatial and temporal variability of antibiotic resistance in freshwater bacterial assemblages. FEMS Microbiol Ecol 13:135-144

Lorenz MG, Wackernagel W (1994) Bacterial gene transfer by natural genetic transformation in the environment. Microbiol Rev 58:563-602

McArthur JV, Tuckfield RC (2000) Spatial patterns in antibiotic resistance among stream bacteria: effects of industrial pollution. Appl Environ Microbiol 66:3722-3726

Meier P, Wackernagel W (2003) Monitoring the spread of recombinant DNA from field plots with transgenic sugar beet plants by PCR and natural transformation of Pseudomonas stutzeri. Transgenic Res 12:293-304

Page RDM (1996) TREEVIEW: an application to display phylogenetic trees on personal computers. Comp Appl Biosciences 12:357-358

Riesenfeld CS, Goodman RM, Handelsman J (2004) Uncultured soil bacteria are a reservoir of new antibiotic resistance genes. Environ Microbiol 6:981-989

Rosenberg DM, Chambers PA, Culp J, Franzin WG and 5 others (2005) Nelson and Churchill River Basins. In: Benke 
AC, Cushing CE (eds) Rivers of North America. Elsevier Academic Press, Burlington, MA

Sèveno NA, Kallifidas D, Smalla K, van Elsas JD, Collard JM, Karagouni AD, Wellington EMH (2002) Occurrence and reservoirs of antibiotic resistance genes in the environment. Rev Med Microbiol 13:15-27

Sharkey FH, Banat IM, Marchant R (2004) Detection and quantification of gene expression in environmental bacteriology. Appl Environ Microbiol 70:3795-3806

Shaw KJ, Rather PN, Hare RS, Miller GH (1993) Molecular genetics of aminoglycoside resistance genes and familial relationships of the aminoglycoside-modifying enzymes. Microbiol Rev 57:138-163

Sikorski J, Teschner N, Wackernagel W (2002) Highly different levels of natural transformation are associated with genomic subgroups within a local population of Pseudomonas stutzeri from soil. Appl Environ Microbiol 68:865-873

Smalla K, van Overbeek LS, Pukall R, van Elsas JD (1993) Prevalence of $n p t I I$ and Tn5 in kanamycin-resistant bacteria from different environments. FEMS Microbiol Ecol 13:47-58

Smith MS, Yang RK, Knapp CW, Niu Y, Peak N, Hanfelt MM, Galland JC, Graham DW (2004) Quantification of tetracycline resistance genes in feedlot lagoons by real-time PCR. Appl Environ Microbiol 70:7372-7377

Sundin GW, Bender CL (1996) Dissemination of the strA-strB streptomycin resistance genes among commensal and

Editorial responsibility: Jed Fuhrman,

Los Angeles, California, USA pathogenic bacteria from humans, animals, and plants. Mol Ecol 5:133-143

Thompson JD, Higgins DG, Gibson TJ (1994) CLUSTAL W: improving the sensitivity of progressive multiple sequence alignment through sequence weighting, position-specific gap penalties and weight matrix choice. Nucleic Acids Res 22:4673-4680

van Elsas JD (1992) Antibiotic resistance gene transfer in the environment: an overview. In: Wellington EMH, van Elsas JD (eds) Genetic interactions between microorganisms in natural environments. Pergamon Press, London, p 17-39

Waters B, Davies J (1997) Amino acid variation in the GYrA subunit of bacteria potentially associated natural resistance to fluoroquinolone antibiotics. Antimicrob Agents Chemother 41:2766-2769

Wireman J, Liebert CA, Smith T, Summers AO (1997) Association of mercury resistance with antibiotic resistance in gram-negative fecal bacteria of primates. Appl Environ Microbiol 63:4494-4503

Yenofsky RL, Fine M, Pellow JW (1990) A mutant neomycin phosphotransferase II gene reduces the resistance of transformants to antibiotic selection pressure. Proc Natl Acad Sci USA 87:3435-3439

Yurieva OG, Kholodii G, Minakhin L, Gorlenko Z, Kalyaeva E, Mindlin S, Nikiforov V (1997) Intercontinental spread of promiscuous mercury resistance transposons in environmental bacteria. Mol Microbiol 24:321-329

Submitted: March 30, 2006; Accepted: January 23, 2007 Proofs received from author(s): June 29, 2007 